\title{
PENGUJIAN FAMA \& FRENCH FIVE-FACTORS ASSET PRICING MODEL PADA INDEKS LQ 45 PERIODE 2014-2018
}

\author{
Ivan Gumilar Sambas Putra1, Neneng Susanti², Okta Eka Putra ${ }^{3}$ \\ 1,2) Fakultas Bisnis dan Manajemen, Universitas Widyatama, Bandung. \\ 3)Magister Ilmu Manajemen, Universitas Pasundan, Bandung
}

\begin{abstract}
Abstrak $\quad$ Penelitian ini bertujuan untuk menguji apakah Fama \& French Five-Factors Asset Pricing Model dapat menjelaskan excess return yang diharapkan oleh investor. Populasi yang digunakan yaitu perusahaan dalam Indeks LQ 45 yang berkapitalisasi besar dan likuid. Teknik pengambilan sampel yang digunakan adalah purposive sampling dengan sampel berjumlah 25 perusahaan. Teknik analisis data yang digunakan adalah analisis regresi berganda. Hasil pengujian menunjukkan bahwa seluruh variabel dalam Fama \& French Five-Factors Asset Pricing Model berpengaruh signifikan secara simultan terhadap excess return dengan besarnya pengaruh adalah $65.7 \%$. Hasil pengujian secara parsial juga menunjukkan bahwa seluruh variabel dalam penelitian ini mempunyai pengaruh signifikan terhadap excess return. Hal ini berarti Fama \& French Five-Factors Asset Pricing Model dalam periode penelitian ini dapat menjelaskan tingkat excess return saham yang diharapkan oleh investor.
\end{abstract}

Kata Kunci : $\quad$ Market Return, Small Minus Big (SMB), High Minus Low (HML), Robust Minus Weak (RMW), Minus Aggressive Conservative (CMA), dan Excess Return

\begin{abstract}
This study aims to examine whether the Fama \& French Five-Factors Asset Pricing Model can explain the excess return expected by investors. The population was all companies of the LQ 45 index with large and liquid capitalization. The sampling technique used was purposive sampling with a sample of 25 companies. The data analysis technique used was multiple regression analysis. The results showed that, simultaneously, all variables in the Fama \& French Five-Factors Asset Pricing Model have a significant effect on excess return with the magnitude of influence of 65.7\%. The partial test results also showed that all research variables have a significant effect on excess return. These findings indicated that the Fama \& French Five-Factors Asset Pricing Model used in the research period could explain the level of the share excess return expected by investors.
\end{abstract}

Keywords : $\quad$ Market Return, Small Minus Big (SMB), High Minus Low (HML), Robust Minus Weak (RMW), Minus Aggressive Conservative (CMA), and Excess Return

\section{Pendahuluan}

Teknik Pasar modal Indonesia mengalami kemajuan semenjak menjadi Bursa Efek Indonesia (BEI) atau yang akhirnya dikenal juga dengan Indonesia Stock Exchange (IDX). Selama periode 2006 hingga 2016 BEI mencatat pertumbuhan indeks pasar sebesar $194 \%$, tertinggi diantara bursa-bursa utama dunia. Tentunya pertumbuhan indeks pasar yang tinggi mendorong perkembangan pasar modal. Pasar modal Indonesia saat ini dalam kondisi yang baik, tentunya hal tersebut tidak lepas dari peran pemerintah selaku regulator dan memberikan stimulus sehingga investor menjadi percaya kepada pasar modal Indonesia. Kinerja pasar modal Indonesia tahun 2016 tercatat menjadi salah satu yang 
terbaik, yaitu berada di peringkat terbaik ke-2 di Asia-Pasifik dan terbaik ke-4 di dunia, beberapa faktor seperti penguatan nilai tukar rupiah terhadap dolar AS, perbaikan perekonomian domestik, pemulihan kredibilitas APBN, serta pelaksanaan amnesti pajak yang baik (www.idx.co.id).

Kinerja pasar modal yang baik ini juga tercermin dari Indeks Harga Saham Gabungan (IHSG) mencapai 6,05 persen. IHSG dalam jangka waktu 5 (lima) tahun terakhir juga mampu mencatatkan kinerja cukup baik dengan return mencapai $\quad 27.114 \%$. Namun demikian pasar modal akan selalu mengalami risiko, jika ditinjau dari sudut pandang investor, salah satu indikator penting untuk menilai prospek perusahaan dimasa yang akan datang adalah dengan melihat perbandingan pertumbuhan perusahaan terhadap risiko yang dihadapi, sehingga investor mampu melihat perusahaan yang memberikan return sesuai dengan tingkat yang diisyaratkan investor.

Investor tentunya mengharapkan keuntungan, keuntungan yang diharapkan adalah berasal dari seberapa besar tingkat pengembalian (return) yang akan diperoleh secara optimal. Namun pada beberapa kasus terdapat perbedaan antara pengembalian yang diterima oleh investor (actual return) dengan tingkat pengembalian yang diharapkan (expected return), sehingga dengan demikian diketahui bahwa setiap investor tidak dapat mengetahui secara pasti seberapa besar pengembalian yang akan diterima (expected return). Keadaan seperti ini menunjukkan bahwa dalam melakukan sebuah kegiatan investasi, maka investor akan menghadapi risiko. Fahmi (2013) menyatakan bahwa dalam teori keuangan menyatakan bahwa jika risiko suatu investasi meningkat maka investor akan mensyarakatkan tingkat pengembalian (expected return) yang lebih tinggi, sehingga dapat dikatakan bahwa risiko adalah faktor penting dalam menentukan keputusan investasi.

Hubungan risk dan return menunjukkan bahwa adanya hubungan positif.. Ketika melakukan kegiatan investasi setidaknya terdapat tiga faktor dasar dalam pengambilan keputusan investasi yaitu terdiri dari pertama, tingkat pengembalian (return), risiko yang akan dihadapi (risk), dan jangka waktu (the time factor). Sehingga kemampuan dalam melakukan estimasi terhadap return suatu sekuritas menjadi penting bagi para investor untuk mentukan keputusan keuangan. Oleh karena itu, para peneliti terus melakukan penelitian dan pengembangan asset pricing model untuk mendapatkan teknik yang terbaik dalam melakukan seleksi terhadap portofolio yang dapat memberikan pengambalian keputusan yang paling optimal bagi investor.

Menurut Fahmi (2015:2) mendefinisikan manajemen keuangan merupakan penggabungan dari ilmu dan seni yang membahas, mengkaji dan menganalisis tentang bagaimana seorang manajer keuangan dengan mempergunakan seluruh sumber daya perusahaan untuk mencari dana, mengelola dana, dan membagi dana dengan tujuan mampu memberikan profit atau kemakmuran bagi para pemegang saham dan keberlanjutan usaha bagi perusahaan. Sedangkan menurut Hanafi (2012:2) manajemen keuangan dapat di artikan sebagai kegiatan perencanaan, pengorganisasian, staffing, pelaksanaan, dan pengendalian fungsi-fungsi keuangan. Berdasarkan pengertian yang telah dikemukakan oleh para ahli maka dapat disimpulkan bahwa manajemen keuangan adalah penggabungan dari ilmu dan seni yang membahas kegiatan seorang manajer yang berhubungan dengan pengaturan aktivitas keuangan (memperoleh aset, mendanai aset, dan mengelola aset) didalam perusahaan sehingga mampu memberikan nilai tambah bagi perusahaan.

Saham merupakan salah satu instrumen pasar modal yang paling diminati investor karena memberikan tingkat keuntungan yang menarik. Saham dapat didefinisikan sebagai tanda penyetaan modal seorang atau sepihak (badan usaha) dalam suatu perusahaan atau perseroan terbatas. Definisi saham menurut para ahli adalah sebagai berikut: Menurut Darmadji dan Fakhruddin (2012: 5), saham dapat didefinisikan sebagai tanda penyertaan atau pemilikkan seseorang atau badan dalam suatu perusahaan atau perseroan terbatas (PT). Sementara Tandelilin (2010:243) memaparkan bahwa saham merupakan surat bukti bahwa kepemilikkan atas asset-aset perusahaan yang menerbitkan saham. Menurut Bodie et al (2014:42), saham adalah bagian kepemilikan dalam suatu perusahaan. Sedangkan menurut Fahmi (2012:81), saham 
merupakan salah satu instrumen pasar modal yang paling banyak diminati oleh investor, karena mampu memberikan tingkat pengembalian yang menarik. Saham adalah kertas yang tercantum dengan jelas nilai nominal, nama perusahaan, dan diikuti dengan hak dan kewajiban yang telah dijelaskan kepada setiap pemegangnya.

Salah satu tujuan investor berinvestasi adalah untuk mendapatkan return. Tanpa adanya tingkat keuntungan yang dinikmati dari suatu investasi, tentunya investor tidak akan melakukan investasi. Fahmi (2012:189), menyatakan return adalah keuntungan yang diperoleh oleh perusahaan, individu dan institusi dari hasil kebijakan investasi yang dilakukannya. Jogiyanto (2015: 205) memaparkan bahwa return merupakan hasil yang diperoleh dari investasi. Return dapat berupa return realisasi yang sudah terjadi yang dihitung berdasarkan data historis dan return ekspektasi yang belum terjadi, tetapi yang diharapkan akan terjadi di masa mendatang. Berdasarkan beberapa pendapat tersebut, return pada dasarnya adalah tingkat pengembalian yang diharapkan atas kegiatan investasi yang telah dilakukan. Legiman (2015) berpendapat bahwa return saham merupakan hasil yang diperoleh dari investasi. Suatu asset financial menunjukkan kesediaan investor menyediakan sejumlah dana pada saat ini untuk memperoleh sebuah aliran dana pada masa yang akan datang sebagai kompensasi atas faktor waktu selama dana ditanamkan dan risiko yang ditanggung.

Investasi merupakan salah satu fungsi dari manajemen keuangan, hal ini erat kaitannya dengan pembelanjaan dana yang dimiliki oleh individu atau kelompok (perusahaan) guna memperoleh keuntungan dimasa yang akan datang, selain itu investasi adalah istilah dengan beberapa pengertian yang berhubungan dengan keuangan dan ekonomi. Istilah tersebut berkaitan dengan akumulasi suatu bentuk aktiva dengan suatu harapan mendapatkan keuntungan pada masa depan. Menurut Jogiyanto (2015:5) investasi dapat didefinisikan sebagai penundaan konsumsi sekarang untuk dimasukkan ke aktiva produktif selama periode waktu yang tertentu. Azis, et al (2015 : 234) menegaskan bahwa investasi adalah sejumlah dana atau sumber daya lainnya yang dilakukan pada saat ini, dengan tujuan memperoleh sejumlah keuntungan di masa datang. Menurut Relly dan Bown (2012:4) mendefinisikan investasi adalah komitmen nilai uang saat ini untuk periode waktu tertentu untuk mendapatkan pembayaran di masa depan yang akan memberikan kompensasi kepada investor untuk (1) waktu dana tersebut dilakukan, (2) tingkat inflasi yang diharapkan, (3) ketidakpastian pembayaran di masa depan. Berdasarkan pengertian yang dikemukakan oleh beberapa ahli, maka dapat disimpulkan bahwa investasi merupakan penundaan konsumsi untuk sejumlah dana atau sumber daya lainnya yang dilakukan pada saat ini agar memperoleh keuntungan di masa mendatang. Keraguan serta pro kontra atas akurasi beta pasar sebagai variabel penjelas satu-satunya CAPM dalam mengestimasi return ekspektasi membawa Three Factors Pricing Model sebagai multifactor model yang sangat berpengaruh. Jika dalam CAPM perilaku return dan risiko hanya ditentukan oleh pasar, Fama dan French menambahkan faktor fundamental perusahaan yaitu ukuran perusahaan (firm size) dan book to market. Dengan demikian, tiga variabel penjelas dalam estimasi return ekspektasi meliputi market premium, size premium, dan book to market premium.

Return bulanan diregresi terhadap market premium, size premium, dan book to market premium yang diformulasikan dalam persamaan berikut:

$\mathrm{E}\left(R_{i}\right)=R_{f}+b_{i}\left[\mathrm{E}\left(R_{m}\right)-R_{f}\right]+s_{i} \mathrm{E}(\mathrm{SMB})+h$ ${ }_{i} \mathrm{E}(\mathrm{HML})+\mathrm{e}$

Keterangan:

E(Ri) : expected return saham i

$\mathrm{Rf} \quad$ : risk free rate asset

$\mathrm{E}(\mathrm{Rm})$ : rate of return on market

SMB : selisih value weighted return portofolio saham kecil dan value weighted return portofolio saham kapitalisasi besar

HML : selisih value weighted return portofolio saham dengan book to market tinggi dan value weighted return portofolio saham book to market rendah. $\mathrm{b}_{\mathrm{i}}, \mathrm{s}_{\mathrm{i}}, \mathrm{h}_{\mathrm{i}}$ : slope regresi. Dalam penelitian ini Fama dan French menambahkan faktor size dan book to market untuk melengkapi peran koefisien beta pasar dalam CAPM yang telah dijelaskan pada bagian sebelumnya. Menurut Susanti (2013) Market return dapat didefinisikan sebagai selisih dari rata-rata setiap bulan dari seluruh saham dengan risk free rate bulanan. Febryan (2015) menyatakan bahwa Market return dapat 
dijadikan oleh investor sebagai alat analisis dalam pengambilan keputusan, apakah akan berinvestasi pada pasar modal atau tidak. Sedangkan menurut Maftuhah (2014) jika positif menunjukkan bahwa investor dapat memilih market return yang bernilai tinggi, karena semakin tinggi market return maka akan semakin tinggi excess return yang diterima oleh investor.

Ukuran perusahaan merupakan simbol yang berhubungan dengan peluang dan kemampuan perusahaan untuk masuk ke pasar modal dan jenis pembiyaan lainnya yang menunjukkan kemampuan meminjam. Berikut adalah definisi ukuran perusahaan menurut para ahli, Mirawati (2014) mendefinisikan ukuran perusahaan adalah suatu skala dimana dapat diklasifikasikan besar kecilnya perusahaan menurut berbagai cara antara lain dengan total aktiva, Loq size, harga pasar saham, dan lain. Menurut Suryanita (2014) mendefinisikan ukuran perusahaan adalah suatu ukuran yang mengambarkan besar kecilnya suatu perusahaan yang ditunjukkan oleh total aktiva perusahaan. Besar kecilnya suatu perusaahaan akan mempengaruhi kemampuan perusahaan dalam menanggung risiko yang mungkin timbul dari berbagai situasi yang dihadapi perusahaan. Trinadewi (2012) Perusahaan besar memiliki risiko yang lebih rendah dari pada perusahaan kecil, hal ini dikarenakan perusahaan besar memiliki control yang lebih baik terhadap terhadap kondisi pasar, sehingga mereka mampu menghadapi persaingan ekonomi.

Selain itu, perusahaan perusahaan besar memiliki lebih banyak sumber daya untuk meningkatkan nilai perusahaan karena memiliki akses yang lebih baik terhadap sumber-sumber informasi eksternal dibansingkan dengan perusahaan kecil. Untuk menyertakan faktor size dalam mengestimasi return ekspektasi, Fama dan French (1993) membentuk portofolio yang merepresentasikan pengaruh faktor risiko size yang disebut sebagai portofolio SMB (small minus big). SMB adalah return atas strategi portofolio yang mengambil posisi long terhadap saham dengan kapitalisasi pasar kecil dan mengambil posisi short atas saham dengan kapitalisasi besar dengan faktor lain. Portofolio SMB didesain untuk mengukur tambahan return yang diterima investor dengan melakukan investasi pada saham berkapitalisasi kecil. Tambahan return ini sering disebut sebagai "size premium". SMB dihitung dengan mengurangkan return saham berkapitalisasi kecil dan return saham berkapital besar dengan rata-rata tertimbang book to market sehingga terbebas dari pengaruh faktor lain tersebut. Hasil perhitungan SMB yang positif menunjukkan bahwa saham berkapitalisasi kecil lebih baik daripada saham berkapitalisasi kecil. Menurut Mirawati (2014), ukuran perushaan diukur dengan menggunakan logaritma natural dari total asset.

Rasio book to market merupakan perbandingan antara current book value of equity per lembar saham dengan market value per lembar saham. Rasio ini menunjukkan seberapa jauh suatu perusahaan mampu menciptakan nilai perusahaan relatif terhadap jumlah modal yang diinvestasikan. Trinadewi (2012) menyatakan rasio book to market dapat menjadi indikator bahwa perusahaan tersebut undervalue atau overvalue. Apabila book value suatu sekuritas lebih kecil dibanding market value (rasio book to market < 1), maka saham perusahaan tersebut overvalued. Sebaliknya, bila book value sekuritas lebih lebih besar dibanding market value (rasio book to market >1), maka saham perusahaan tersebut undervalued. Sudiyatno (2011) memperkuat bukti bahwa book to market berkorelasi positif dengan return sekuritas. Pasar memandang perusahaan dengan rasio book to market tinggi sebagai saham yang undervalued yang lebih berisiko dibanding perusahaan dengan rasio book to market rendah sehingga investor mengharap return yang lebih tinggi sebagai kompensasi risiko yang lebih besar.

Untuk menyertakan faktor book to market dalam mengestimasi return ekspektasi, Fama dan French (1993) membentuk portofolio yang merepresentasikan pengaruh faktor risiko book to market yang disebut sebagai portofolio HML (high minus low). HML adalah return atas strategi portofolio yang mengambil posisi long terhadap saham dengan book to market tinggi dan mengambil posisi short atas saham dengan book to market rendah dengan faktor lain. Portofolio HML didesain untuk mengukur tambahan return yang diterima investor dengan melakukan investasi pada saham perusahaan dengan nilai book to market tinggi. Tambahan return ini sering 
disebut sebagai "value premium". HML dihitung dengan mengurangkan return saham yang memiliki book to market tinggi dan return saham yang memiliki book to market rendah dengan rata-rata tertimbang faktor size terbebas dari pengaruh faktor lain tersebut. Hasil perhitungan HML yang positif menunjukkan bahwa saham dengan book to market tinggi menghasilkan return lebih baik daripada saham dengan book to market rendah.

Hasil penelitian Fama dan French (2014) menunjukkan bahwa nilai faktor HML berlebihan untuk menggambarkan pengembalian rata-rata ketika faktor profitabilitas dan investasi telah ditambahkan dalam persamaan. Hasilnya juga menunjukkan bahwa Fama dan French Five-Factors Asset Pricing Model menjelaskan antara 71\% sampai $94 \%$ dari varians yang diharapkan. Telah terbukti bahwa Fama dan French Five-Factors Asset Pricing Model yang diarahkan untuk menangkap pola ukuran perusahaan, book to market, profitabilitas, dan investasi pada return saham memberikan penjelasan yang lebih baik. Model baru ini menunjukkan bahwa expected return tertinggi yang dicapai oleh perusahaan dengan manfaat dan nilai perusahaan dengan prospek pertumbuhan (Fama dan French, 2014).

Model penilaian menunjukkan bahwa ada kemungkinan model yang lebih lengkap untuk mendapatkan expected return karena tiga faktor kurang menjelaskan hubungan antara return untuk profitability dan investasi. Fama dan French (2014) memperkenalkan model penentuan harga aset yang dikenal sebagai Fama dan French Five-Factors. Penelitian ini masih menarik dan perlu dilakukan karena untuk menggungkap apakah Five-Factors mampu menjelaskan expected return lebih baik dari model sebelumnya, selain itu masih sangat sedikit penelitian yang menggunakan Fama dan French Five-Factors . Dilakukannya penelitian ini akan memberikan gambaran kepada pemangku kepentingan terutama investor untuk menghitung return saham yang dapat mereka peroleh. Asset Pricing Model yang mencoba menjelaskan hubungan antara variabel baru dan expected return dari perspektif model diskon dividen dan teori penilaian. Dalam penelitian ini, Fama dan French merekomendasikan untuk menggunakan profitabilitas dan faktor investasi, selain faktor-faktor yang sudah ada (risiko pasar, ukuran perusahaan dan book to market) untuk menangkap pola dalam ratarata expected return.

Dalam portofolio investasi terdapat model yang sering digunakan investor dalam memprediksi tingkat keuntungan (expected return), yaitu Capital Asset Pricing Model (CAPM), Arbitrage Pricing Theory (APT), Fama dan French Three Factor Asset Pricing Models, Carhart Four Factor Asset Pricing Models, sampai pada akhirnya pada tahun 2014 Fama dan French kembali mengembangkan dari yang sebelumnya adalah Three factor menjadi Five-Factors Asset Pricing Model, yang menambahkan dua faktor baru yaitu profitabilitas dan investasi. Adanya perkembangan terus menerus mengenai teori Asset Pricing menyebabkan penelitian dalam teori ini sangat menarik untuk dilakukan dan mendapatkan hasil dalam mendukung teori yang ada.

\section{Metodologi}

Jenis data yang digunakan dalam penelitian ini seluruhnya merupakan data sekunder, yaitu data yang telah dipublikasikan seperti Indonesia Capital Market Direktory (ICMD), Annual Report yang diunggah dari situs www.idx.co.id dan situs lainnya seperti www.finance.yahoo.com, www.sahamok.com, www.bi.go.id. Metode penelitian yang digunakan dalam penelitian ini adalah metode penelitian eksplanatori. Dalam penelitian ini metode tersebut digunakan untuk menjawab permasalahan mengenai pengaruh FamaFrench Five Factors Model terhadap excess return saham. Proses pengambilan sampel dalam penelitian ini menggunakan purposive sampling. Adapun populasi dalam penelitian ini adalah Indeks LQ45 yang terdiri dari 45 perusahaan yang sahamnya memiliki likuiditas tinggi yang diseleksi melalui beberapa kriteria pemilihan. Diantara sahamsaham yang ada di pasar modal Indonesia, saham LQ45 yang ada di Bursa Efek Indonesia merupakan saham yang banyak diminati oleh para investor. Hal ini dikarenakan saham LQ45 memiliki kapitalisasi tinggi serta frekuensi perdagangan yang tinggi sehingga prospek pertumbuhan dan kondisi keuangan saham baik. 
Adapun kriteria-kriteria penentuan sampel yang digunakan dalam penelitian ini adalah sebagai berikut (1) perusahaan yang diteliti merupakan perusahaan yang tercatat di LQ45 periode 2014 - 2018; (2) perusahaan yang listing pada LQ45 secara berturut-turut dari tahun 2014 - 2018. Dari 45 perusahaan yang listing di LQ45 secara berturut-turut dari tahun 2014 sampai 2018, yakni 25 perusahaan yang terpilih menjadi sampel penelitian. Jenis data yang digunakan dalam penelitian ini adalah cross section. Variabel dependent yang berkaitan dengan masalah yang akan diteliti adalah excess return. Sedangkan variabel bebas yang berkaitan dengan masalah yang akan diteliti adalah market premium, small minus big (SMB), high minus low (HML), Robust Minus Weak (RMW) dan Minus Aggressive Conservative (CMA).

\section{Hasil dan Pembahasan}

\section{Uji Model Fama \& French Five Factors ( $\mathrm{R}^{2}$ )}

Hasil penelitian Fama dan French (2014) menunjukkan bahwa nilai faktor HML berlebihan untuk menggambarkan pengembalian rata-rata ketika faktor profitabilitas dan investasi telah ditambahkan dalam persamaan. Hasilnya juga menunjukkan bahwa Fama dan French Five-Factors Asset Pricing Model menjelaskan antara 71\% sampai 94\%. Telah terbukti bahwa Fama dan French Five-Factors Asset Pricing Model yang diarahkan untuk menangkap pola ukuran perusahaan, book to market, profitabilitas, dan investasi pada return saham rata-rata memberikan penjelasan yang lebih baik. Model baru ini menunjukkan bahwa mengembalikan harapan tertinggi yang dicapai oleh perusahaan menggunakan nilai perusahaan dengan prospek pertumbuhan (Fama dan French, 2014).

Tabel 1. Hasil Uji Model Fama-French Five Factors $\left(\mathbf{R}^{2}\right)$

\begin{tabular}{llll}
\hline $\mathrm{R}$ & $\mathrm{R}$ Square & Adj R Square & Sig. \\
\hline $0.729 \mathrm{a}$ & 0.657 & 0.619 & 0.000 \\
\hline $\begin{array}{l}\text { Predictors: (Constant), } \\
\text { WML, RMW, CMA }\end{array}$ & & & \\
Dependent Variable: ExcessReturn & SMB, HML,
\end{tabular}

Sumber : data diolah, 2019

Diketahui bahwa variabel market return $\left(\mathrm{X}_{1}\right)$, small minus big (SMB) $\left(\mathrm{X}_{2}\right)$, high minus low (HML) (X3), Robust Minus Weak (RMW) (X4) dan Minus Aggressive Conservative (CMA) (X5) menjelaskan variasi Excess Return (Y) sebesar 65.7 persen, sisanya 34.3 persen ditentukan oleh variabel-variabel lain di luar model. Hal ini menunjukkan bahwa investor dapat menggunakan market return, small minus big (SMB), high minus low (HML), Robust Minus Weak (RMW) dan Minus Aggressive Conservative (CMA) sebagai indikator untuk mempertimbangkan return saham yang dapat digunakan sebagai dasar pengambilan keputusan untuk berinvestasi.

\section{Hasil Uji Hipotesis F}

Tabel 2. Hasil Uji Hipotesis F Model FamaFrench Five Factors

\begin{tabular}{llllll}
\hline Model & $\begin{array}{l}\text { Sum of } \\
\text { Square }\end{array}$ & Df & $\begin{array}{l}\text { Mean } \\
\text { Squar } \\
\text { e }\end{array}$ & F & Sig. \\
\hline Regression & 8.238 & 5 & 2.035 & 5.317 & $.000^{\mathrm{b}}$ \\
Residual & 5.914 & 119 & .371 & & \\
Total & 14.152 & 124 & & & \\
\hline Dependent Variable: ExcessReturn & & \\
Predictors: (Constant), MarketReturn, SMB, HML,RMW, \\
CMA
\end{tabular}

Sumber : data diolah, 2019

Dari uji F tersebut diketahui bahwa F statistik adalah sebesar 5.317 sedangkan $F$ tabel dengan tingkat signifikansi $5 \%$ diperoleh $\mathrm{F}$ tabel sebesar 2,32 dalam hal ini maka F-hitung / F-statistik lebih besar dari F-table, artinya terdapat pengaruh signifikan antara variabel market return $\left(\mathrm{X}_{1}\right)$, small minus big (SMB) $\left(\mathrm{X}_{2}\right)$, high minus low (HML) (X3), Robust Minus Weak (RMW) (X4) dan Minus Aggressive Conservative (CMA) (X5) secara simultan terhadap excess return.

\section{Pembahasan}

Dari penelitian ini ditemukan bahwa market return $\left(\mathrm{X}_{1}\right)$, small minus big (SMB) $\left(\mathrm{X}_{2}\right)$, high minus low (HML) (X3), Robust Minus Weak (RMW) (X4) dan Minus Aggressive Conservative (CMA) (X5) berpengaruh secara bersama-sama terhadap excess return saham, besarnya pengaruh adalah $65.7 \%$. Hal ini berarti investor dapat menggunakan nilai market return, small minus big (SMB), high minus low (HML), Robust Minus Weak(RMW) dan Minus Aggressive Conservative (CMA) sebagai indicator untuk mempertimbangkan excess return saham yang selanjutnya dapat digunakan sebagai dasar pengambilan keputusan untuk investasinya. Sedangkan bagi perusahaan dengan adanya penelitian ini 
memberikan masukan dalam pengambilan keputusan bagi manajemen dalam mengelola fundamental perusahaan agar dapat memberikan sentiment positif, hal ini dilakukan dengan memperhatikan variablevariabel dalam penelitian ini.

Pemerintah sendiri sebagai regulator dalam penelitian ini melalui lembaga terkait tentunya dapat melakukan pengawasan serta sosialisasi dan intervensi kepada emiten maupun pasar dalam hal pengelolaan serta regulasi untuk mempermudah emiten dalam mengakses kebijakan serta menciptakan sentiment positif melalui Bank Indonesia sangat diperlukan agar pasar selalu dalam keadaan stabil dan Bank Indonesia harus selalu menjaga Posisi Investasi Internasional (PII) Indonesia, karena hal ini akan memberikan sentimen yang dapat berdampak positif dan negative terhadap investor. Hasil penelitian ini sesuai dengan penelitian yang dilakukan oleh Fama \& French (2014), Chiah et al. (2015) dan Wijaya et al (2017) yang menyatakan bahwa Five Factors asset pricing model yang dikemukan oleh Fama \& French memiliki kemampuan yang paling baik dalam menjelaskan return saham.

Berdasarkan hasil pengujian parsial bahwa terdapat hubungan yang signifikan antara market return (X1) terhadap excess return saham (Y) pada saham-saham LQ45 periode 2014-2018 dengan arah positif, hal ini menunjukkan bahwa market return mempunyai pengaruh positif dan signifikan terhadap excess return saham. Hasil uji yang berpengaruh positif menunjukkan bahwa investor dapat memilih market return yang bernilai tinggi, karena semakin tinggi market return maka akan semakin tinggi excess return yang diterima oleh investor, atau dapat juga diartikan bahwa market return yang bernilai positif menunjukkan kondisi pasar sedang bullish, yang artinya investor dapat mengambil keputusan untuk berinvestasi pada pasar modal. Hal ini berarti investor dapat menggunakan nilai market return sebagai salah satu indikator untuk mempertimbangkan excess return saham yang selanjutnya dapat digunakan sebagai dasar pengambilan keputusan untuk investasinya.
Hasil penelitian ini sesuai dengan penelitian yang dilakukan oleh Nur'ainy et al. (2013) yang menyatakan bahwa risiko faktor pasar memiliki kekuatan untuk menjelaskan tingkat pengembalian. Hasil penelitian yang dilakukan oleh Sudiyatno dan Irsad (2011) juga menyatakan bahwa Return pasar berpengaruh positif dan signifikan terhadap return saham. Semakin tinggi return pasar, maka semakin tinggi excess return saham. Penelitian lain yang juga sejalan adalah penelitian dilakukan oleh Fawziah (2016) Premi Risiko berpengaruh positif dan signifikan terhadap return saham. perusahaan pertambangan yang terdaftar di Bursa Efek Indonesia pada bulan 2007-September 2015.

Hasil penelitian yang dilakukan oleh Susanti (2013) juga memperoleh hasil yang sama dengan penelitian ini yaitu market return memiliki pengaruh yang signifikan terhadap excess return. Hasil penelitian yang dilakukan oleh Irsyad (2012) menyatakan bahwa Risk premium (premi risiko) berpengaruh positif dan signifikan terhadap excess return saham. Semakin tinggi risk premium (premi risiko), semakin tinggi excess return saham. Penelitian yang dilakukan oleh Candika (2017) juga menghasilkan bahwa variabel excess market return (Rm-Rf) berpengaruh positif signifikan terhadap excess return saham pada semua portofolio saham yang digunakan dalam penelitian ini. Penelitian yang dilakukan oleh Eraslan (2013) juga mendapati bahwa factor risiko pasar atau pengembalian pasar memiliki pengaruh yang lebih luas terhadap portfolio.

Berdasarkan hasil pengujian parsial bahwa terdapat hubungan yang signifikan antara small minus big (SMB) (X2) terhadap excess return saham (Y) pada saham-saham LQ45 periode 2014-2018 dengan arah positif, hal ini menunjukkan bahwa market return mempunyai pengaruh positif dan signifikan terhadap excess return saham. Sehingga dengan demikian investor sebagai pemilik modal jika akan melakukan kegiatan investasi dapat memperhatikan nilai dari small minus big (SMB). Hasil uji yang berpengaruh positif menunjukkan bahwa sebaiknya investor memilih saham dari perusahan dengan nilai kapitalisasi kecil, karena akan memberikan excess return yang lebih tinggi. Hal ini berarti 
investor dapat menggunakan nilai kapitalisasi pasar sebagai salah satu indicator untuk mempertimbangkan excess return saham yang selanjutnya dapat digunakan sebagai dasar pengambilan keputusan untuk investasinya.

Hasil penelitian ini sesuai dengan penelitian yang dilakukan oleh Penelitian yang dilakukan oleh Lestari (2015) bahwa Size SMB memiliki pengaruh positif dan signifikan terhadap expected return. Selanjutnya hasil penelitian yang dilakukan oleh Pitriyanti, et al. (2015) menyatakan bahwa return market berpengaruh signifikan sehingga dapat digunakan sebagai risiko dalam menjelaskan naik turunnya tingkat pengembalian (return) pada setiap portofolio Fama and French. Penelitian yang dilakukan oleh Candika (2017) juga menghasilkan bahwa variabel size (SMB) berpengaruh positif signifikan terhadap excess return saham pada 5 portofolio.

Berdasarkan hasil pengujian parsial bahwa terdapat hubungan yang signifikan antara High minus Low (HML) (X3) terhadap excess return saham (Y) pada saham-saham LQ45 periode 2014-2018 dengan arah positif, hal ini menunjukkan bahwa high minus low (HML) mempunyai pengaruh positif dan signifikan terhadap excess return saham. Hasil uji yang berpengaruh positif menunjukkan bahwa sebaiknya investor memilih saham dari perusahan dengan nilai book to market yang tinggi, karena nilai book to market yang tinggi akan memberikan excess return yang lebih tinggi atau lebih baik bagi investor. Hasil penelitian yang dilakukan oleh Putri (2016) menyatakan bahwa Market to book value (HML) berpengaruh positif signifikan terhadap return saham pada perusahaan industri barang konsumsi di Bursa Efek Indonesia. Penelitian yang dilakukan oleh dilakukan oleh Lestari (2015) menyatakan bahwa Book to market value (HML) memiliki pengaruh positif dan signifikan terhadap ecxess return. Penelitian yang dilakukan oleh Candika (2017) menghasilkan bahwa variabel book to market ratio (HML) berpengaruh positif signifikan terhadap excess return saham.

Berdasarkan hasil pengujian parsial bahwa terdapat hubungan yang signifikan antara Robust Minus Weak (RMW) (X4) terhadap excess return saham (Y) pada saham-saham LQ45 periode 2014-2018 dengan arah positif, hal ini menunjukkan bahwa Robust Minus Weak (RMW) mempunyai pengaruh positif dan signifikan terhadap excess return saham. Hasil uji yang berpengaruh positif menunjukkan bahwa sebaiknya investor memilih saham dari perusahan dengan nilai profitabilitas yang tinggi, karena nilai profitabilitas yang tinggi akan memberikan excess return yang lebih tinggi atau lebih baik bagi investor. Hal ini juga disebabkan karena investor berasumsi bahwa manajemen yang mampu mengelola perusahaan dengan baik akan memeberikan keuntungan bagi perusahaan, terutama keuntungan atas hasil kegiatan bisnis yang dilakukan oleh perusahaan. Hasil penelitian ini sejalan dengan yang dilakukan oleh Fama \& French (2014), Chiah et al. (2015) dan Wijaya et al. (2017) yang menyatakan bahwa Robust Minus Weak (RMW) memiliki pengaruh terhadap excess return.

Berdasarkan hasil pengujian parsial bahwa terdapat hubungan yang signifikan antara Minus Aggressive Conservative (CMA) $\left(\mathrm{X}_{5}\right)$ terhadap excess return saham (Y) pada sahamsaham LQ45 periode 2014-2018 dengan arah positif, hal ini menunjukkan bahwa Minus Aggressive Conservative (CMA) mempunyai pengaruh positif dan signifikan terhadap excess return saham. Hasil uji yang berpengaruh positif menunjukkan bahwa sebaiknya investor memilih saham dari perusahan dengan nilai investasi yang tinggi, karena nilai investasi yang tinggi akan memberikan excess return yang lebih tinggi atau lebih baik bagi investor. Dalam kondisi ini investor melihat bahwa perusahaan yang melakukan kegiatan investasi bearti mampu mengelola dan memiliki harapan eksistensi dimasa yang akan datang, sehingga ada aspek keamanan serta keuntungan secara jangka panjang yang investor ekspektasi. Hasil penelitian yang dilakukan oleh Fama \& French (2014), Chiah et al. (2015) dan Wijaya et al. (2017) yang menyatakan bahwa Minus Aggressive Conservative (CMA) memiliki pengaruh terhadap excess return. 


\section{Kesimpulan}

Teknik Berdasarkan pengujian dapat secara simultan disimpulkan bahwa market return $\left(\mathrm{X}_{1}\right)$, small minus big (SMB) $\left(\mathrm{X}_{2}\right)$, high minus low (HML) (X3), Robust Minus Weak (RMW) (X4) dan Minus Aggressive Conservative (CMA) (X5) berpengaruh signifikan terhadap excess return (Y) pada saham dalam indeks LQ45 periode 2014-2018. Sedangkan berdasarkan hasil pengujian secara parsial bahwa terdapat hubungan yang signifikan seluruh variabel Fama and French FiveFactors Asset Pricing Model yang terdiri dari Market return (X1), Small minus big (SMB) (X2), High minus low (HML) (X3), Robust Minus Weak (RMW) (X4), dan Minus Aggressive Conservative (CMA) (X5) terhadap excess return (Y) pada indeks LQ 45 periode 2014-2018.

\section{Saran}

Penelitian ini masih mengandung beberapa keterbatasan dan diharapkan dapat disempurnakan dalam penelitian-penelitian selanjutanya, adapun saran-saran secara akademis maupun paktis yang dapat diberikan yaitu penelitian ini hanya terbatas pada Indeks LQ45, oleh karena itu para peneliti selanjutnya dapat melibatkan indeks yang lain atau pada sektor industri lain sehingga hasil penelitiannya menjadi lebih komprehensif. Penelitian hanya menggunakan sampel dengan periode riset selama 5 tahun (20142018). Para peneliti selanjutnya disarankan untuk memperpanjang periode riset. Para investor dalam menginvestasikan dananya ke dalam sebuah sekuritas, hendaknya terlebih dahulu melakukan identifikasi dan memahami setiap perkembangan yang terjadi pada sekuritas tersebut. Investor harus mampu mengetahui bagaimana faktor-faktor yang dapat mempengaruhi pergerakan harga atau return yang mampu diciptakan atau dihasilkan oleh perusahaan sebagai kontribusi perusahaan kepada para investornya. Salah satu cara yang dengan menggunakan Fama \& French Five Factors Model. Perusahaan harus lebih berkomitmen, konsisten dan fokus pada hal-hal yang menjadi tujuan bersama, salah staunya yaitu meningkatkan kinerja perusahaan sehingga hal ini akan mampu membuat kepercayaan investor untuk menginvestasikan dananya kepada perusahaan akan meningkat. Dengan beberapa faktor yang dapat menjadi sebuah pertimbangan bagi perusahaan dalam mengambil langkah yang tepat untuk memberikan kontribusi dalam membentuk perilaku harga atau return yang lebih meningkat sehingga kesejahteraan baik dari investor, maupun pihak internal perusahaan juga dapat merasakan manfaat yang diberikan oleh perusahaan.

\section{Daftar Referensi}

Azis, M., Mintarti, S., Nadir, M. 2015. Manajemen Investasi Fundamental, Teknikal, Perilaku Investor dan Return Saham. Yogyakarta: DEEPUBLISH (Grup Penerbitan CV BUDI UTAMA).

Bodie, Kane, \& Marcus. 2014. Manajemen Portoflio dan Investasi. Jakarta: Salemba Empat

Candika, Yossy Imam. 2017. Pengujuan Kekuatan Model Charhart Empat Faktor Terhadap Excess Return Saham Di Indonesia. The Indonesian Journal of Applied Business Volume 1, No. 1, April 2017

Chiah, M., Chai, D., Zhong, A., 2015, A Better Model? An EmpiricalInvestigation of FamaFrench Five-Factor Model in Australia, Proc,Monash Business School, Monash University.

Darmadji, T.H.M Fakhrudin. 2012. Pasar Modal di Indonesia. Edisi Ketiga. Salemba Empat, Jakarta.

Eraslan, Veysel. 2013. Fama French Three-Facrot Model : Evidence From Istanbul Stock Exchange. Business and Economucd Research Journal Volume 4 Number 2, 2013.

Febryan, Fandi. 2015. Analisis Penerapan CAPM Dalam Menilai Investasi Pada Saham Jakarta Islamic Indeks Periode 2011 - 2013

Fahmi, Irham. 2012. Pengantar Manajemen Keuangan. Bandung: Alfabeta

Fahmi, Irham. 2013. Analisis Laporan Keuangan. Bandung: Alfabeta.

Fahmi, Irham. 2015. Manajemen Investasi. Bandung: Alfabeta.

Fama, E.F., dan K.R. French. 1993. "Common Risk Factors in the Returns on Stocks and Bonds". Journal of Finance. Vol. 48. Page.3-56. 
Fama, E.F. dan French, K.R. 2014. A Five-Factor Asset Pricing Model, Journal of Financial Economics, 116.

Fawziah, Siti Apriani. 2016. Pengaruh Rama-French Three Factor Model Terhadap Return Perusahaan. Yogyakarta : Universitas Negeri Yogyakarta.

Jogiyanto. 2015. Teori Portofolio dan Analisis Investasi. Yogyakarta: Universitas Gajah Mada.

Lestari, Alfi Muflikhah dan Setyo Tri Wahyudi. 2015. Pengaruh Model Tiga Factor Fama dan French Terhadap Expected Return : Studi Pada Tujuh Saham Perbankan Konvensional di Indonesia. Malang : Universitas Brawijaya.

Legiman, Fachreza Muhammad, et al. 2015. Faktorfaktor yang memoengaruhi return saham pada perusahaan agroindustry yang terdaftar di Bursa Efek Indonesia periode 2019-2012. Jurnal EMBA vol.3 No.3.

Mirawati. 2014. Pengaruh Kepemilikan dan Ukuran Perusahaan Terhadap Profabilitas pada Perusahaan Property dan Realestate yang Terdaftar di Bursa Efek Indonesia. Tanjung Pinang : Universitas Raja Ali Haji.

Maftuhah, H. 2014. Perbandingan Metode CAPM dan APT dalam Menghitung Return Saham JII. Skrpsi.

Pitriyanti, et al. 2015. Perbandingan Capital Asset Pricing Model (CAPM) dan Three Factor Model Fama and French (TFMFF) dalam Mengestimasi Return Saham. E-Jurnal Matematika Vol. 4 (4), November 2015, pp. 181-187.

Putri, Ni Luh Putu Ika Ardina dan Diantini, Ni Nyoman Ayu. 2016. Analisis Penilaian Pasar Terhadap Return Saham Pada Industri Barang Konsumsi. E-Jurnal Manajemen Unud, Vol. 5, No.8, 2016: 5070-5097 ISSN : 2302-8912.

Relly, F. K., \& Brown, K. C.2012. Investment analysis and portfolio management (10th ed.). Mason, OH: South-Western Cengage Learning. ISBN: 9780538482387.

Susanti, Neneng. 2013. Pengujian Fama and French Three Factor Model PadaPerusahaan di Indonesia yang Sahamnya Terdapat di LQ 45 Tahun 2005-2009. Forum Keuangan \& Bisnis II, Th. 2013, ISBN: 978-602-17225-1-0.

Sudiyatno, Bambang dan Irsad, Moch. 2011. Menguji Model Tiga Faktor Fama Dan French Dalam Mempengaruhi Return Saham Studi Saham LQ 45 di Bursa Efek Indonesia. Jurnal Bisnis dan Ekonomi (JBE), September 2011, Hal. 126 - 136 Vol. 18, No. 2 ISSN: 1412-3126.
Suryanita dan Dinnul Alfian Akbar. 2014. Pengaruh Ukuran Perusahaan dan earning Per share Terhadap Kebijakan Dividen di Bursa Efek Indonesia. Palembang : STIE Multi Data Palembang.

Tandelilin, E. 2010. Portofolio Dan Investasi (Teori Dan Aplikasi). Edisi Pertama. KANISIUS.Yogyakarta.

Trisnadewi, Mariana. 2012. Analisis Pengaruh Risiko Pasar, Size, Book to Market, dan Momentum Terhadap Return Saham. Skripsi Sarjana Fakultas Ekonomika dan Bisnis Universitas Diponegoro Semarang.

Wijaya, Sheila Citra, Werner Murhadi, Mudji Utami. 2017. Analisis Fama French Five Factor Model dan Three Factor Model Dalam Menjelaskan Return Portofolio Saham. Roundtable for Indonesian Entrepreneurship Educators (RIEE)-5. 